\title{
Exploring Vocational Education Students' Visions of a Successful Transition to Working Life from the Perspective of Societal Belonging
}

\section{Susanna Ågren ${ }^{1}$}

Received: 10 July 2020 / Revised: 8 March 2021 / Accepted: 19 March 2021 /

Published online: 6 April 2021

(C) The Author(s) 2021

\begin{abstract}
The emphasis on paid employment is strong in Finnish vocational education. However, the world of work is changing and becoming more insecure. Many researchers have expressed concern about the impact of these uncertainties on employment opportunities for young people. This paper discusses vocational education students' possibilities for societal belonging in their transition to the changing labour market in Finland. It explores the students' visions of a successful transition to working life and a decent life after this transition. The qualitative data were collected by organising six functional workshops for vocational students (58 participants). In the conclusion, the paper argues that in the vocational students' visions, paid employment constitutes an important definer of their societal belonging. Furthermore, it demonstrates how strongly the traditional ideals of worker-citizenship fostered in vocational education influence the meanings the second- and third-year students ascribe to societal belonging. The paper suggests that this issue needs to be critically examined in view of the changing labour market. The question is whether vocational training is able to guarantee graduating young people a realistic opportunity to build their belonging to society while at the same time to responding to the needs of the labour market.
\end{abstract}

Keywords Societal belonging · Worker-citizenship · Vocational education · Youth transitions $\cdot$ Working life $\cdot$ Capability approach

\section{Introduction}

Finding paid employment has been a traditional marker of success in young people's transition to adulthood, for example after graduation (e.g. Wyn and White 1997, 95).

Susanna Ågren

susanna.agren@tuni.fi

1 Faculty of Social Sciences, Tampere University, Tampere, Finland 
For many young people, this marker of adulthood is becoming more difficult to attain in today's economically insecure society (Furlong and Cartmel 2007; Cuervo and Wyn 2016; Chesters and Cuervo 2019). Scholars have argued that some young people hesitate or even refuse to view their success in this transition solely based on its social markers, that is leaving home, finding a permanent job and starting a family (Aronson 2008; Mary 2012). Nevertheless, studies have also shown that the personal feeling of responsibility appears be a central marker of adulthood for young people today, and in this respect, financial independence remains important (Aronson 2008, 64-65; Mary 2012, 278). For example, according to studies conducted in Finland, young people still value work highly because they see it as a significant tool for self-realisation and a part of a good life (Pyöriä et al. 2017; Myllyniemi and Haikkola 2020). Therefore, this paper is interested in these complex meanings of work in the context of traditionally working life-centred vocational education.

The traditional goal of vocational education, to produce new skilled (young) workers for the labour market, has recently been challenged. While the ideal of the workercitizen has maintained its importance as the prime motivator of vocational education, the labour market itself has altered significantly. For example, the developments of globalisation and technologisation have affected the availability of jobs, reducing routine and low-skilled work (Pajarinen et al. 2015; Kerr et al. 2020). These differences in employment prospects, however, vary dramatically between regions and vocational fields, with some being more vulnerable to change and uncertainty than others (Ojala et al. 2018, 158; Kerr et al. 2020, 1031). Studies in Finland have found that the relationship between permanent jobs and precarious employment has remained relatively stable since the 1980s (Pyöriä and Ojala 2016; Rasmussen et al. 2019, 24). At the same time, however, precarious (part-time, fixed-term, temporary agency and selfemployment) work and related economic uncertainties seem to accumulate to certain population groups, such as young people with low levels of education or young immigrants (Pyöriä and Ojala 2016, 362-363; Ojala et al. 2018, 151; Rasmussen et al. 2019, 16; Maury 2020, 815-816). Some researchers assume that the precarious position of young people is an intermediate stage that will be corrected in the future (Pyöriä and Ojala 2016, 363; Ojala et al. 2018, 151). Others, however, have expressed concern that the working life skills provided by vocational education are no longer able to meet the growing demands of the changing labour market (Rintala and Nokelainen 2018; also, Kerr et al. 2020, 1031).

In this context, it is important to study young vocational students' perceptions of their future working life transitions and determine whether (or if) the changes and the new demands of the labour market are reflected in them. More specifically, this paper is interested in vocational students' understanding of their belonging in society, as well as how the ideal of the worker-citizen impacts their sense of belonging and capability to participate in society. Subsequently, the paper works with two theoretical concepts: societal belonging and capabilities. The paper follows May's $(2013,83)$ understanding of belonging; in other words, it sees vocational students' experience of post-transition belonging as built on negotiations with various social groups - i.e. with their friends and peers, family, vocational education communities and society in general. Consequently, by belonging, the current paper refers to vocational students' experience of being accepted as meaningful and respected members of these groups (Anthias 2006, 21). This experience, along with the opportunity to direct one's life, helps guarantee 
one's well-being in society and ensure that one can live a decent life in it (Nussbaum 2011, 39). Relying on this starting point of Nussbaum's (2011) capabilities approach (CA), the paper examines how vocational students perceive their opportunities to view themselves as valued citizens after their transition to work. With CA, the aim of the paper is to stimulate discussion about whether vocational education is currently able to guarantee students the capabilities they need to find their place in society, the labour market notwithstanding.

As to its empirical context, the paper focuses on Finland, where vocational education is relatively popular. Finnish young people begin upper secondary education at the age of 16. They can then choose between two three-year tracks: academic (general) or vocational, with the latter strongly geared to the labour market. Approximately half of the young choose vocational education. The basic objective of Finnish vocational education is to provide society with skilled workers and, by the same token, ensure that young people have the skills to participate in society (Lappalainen et al. 2019; Isopahkala-Bouret et al. 2014). However, several Finnish scholars, adopting a critical tone, have pointed out that vocational education's mission seems to be to educate worker-citizens whose post-graduation participation in society is realised mainly via working life and work communities (Isopahkala-Bouret et al. 2014; also, Nylund et al. 2018; Lappalainen et al. 2019, 347). Isopahkala-Bouret et al. (2014) have argued that this ideal of citizenship imposes strong responsibilities in the form of employability, activity and well-being on vocational students. Given current labour market changes, this may become a problem, hampering young people's chances to belong to and participate in society. This point will be elaborated on as the argument of the paper progresses.

The data for the study were collected from two Finnish vocational education providers. In cooperation with the nation-wide ALL-YOUTH research project, six functional workshops were organised for vocational students nearing graduation. The participants were second- and third-year students aged 17 to 25 from six vocational upper secondary programmes. The data-collages and group interviews-were analysed by applying thematic analysis.

The next section presents a review of the concept of societal belonging and its relationship to $\mathrm{CA}$, followed by a description of the methodology employed in the analysis and a presentation of the main findings. The discussion of the paper aims to contribute to recent research debates around vocational students' working life transitions given current economic insecurities and their impacts on young people.

\section{Societal Belonging-Opportunity or Responsibility?}

According to Wood (2017), by investigating the connections between young people's transition to working life and their sense of belonging in society, it is possible to understand more deeply what it is to be a young person today (see also Cuervo and Wyn 2014). Investigating vocational education graduates' sense of societal belonging can uncover their complex position in the changing labour market (May 2013, 4-6). Hence, it is reasonable to examine how the ideal of the worker-citizen manifests in vocational students' visions of a 'successful transition' and self-perceived potential to achieve societal belonging (Wood 2017, 1182). 
Lähdesmäki et al. (2016) highlight the complexity and convoluted nature of the concept of belonging. However, they also find the concept useful for studying people's social relations and practices at the personal, social and societal levels because it directs attention toward the power relationships that justify and sometimes deny belonging (ibid., 241-242). Accepting this argument, the paper views belonging as a two-sided phenomenon, exploring how the personal dimension of belonging is constructed and how society's power relationships enable (or disable) belonging (see Antonsich 2010). By reference to May (2011, 367-368), this paper sees belonging in a person-centred way, paying attention to how people actively construct their connections to the surrounding world in their everyday lives. The aim is to understand belonging not only in terms of the personal longing to be part of something but also in terms of the 'politics of belonging' (Yuval-Davis 2006). The latter refer to the relations of power in the context in which some people are seen as belonging while others are rendered outsiders. In other words, a person's potential to construct a sense of belonging depends on the way other people and wider society acknowledge that individual's right to belong (Yuval-Davis 2006, 203, 207-208; Antonsich 2010, 649-650; May 2013, 83; Lähdesmäki et al. 2016; 239-240; May 2016, 759).

Although the paper's focus is on post-transition belonging among young people, it is worth noting that belonging is a constantly changing process (May 2011, 372). Nevertheless, an examination of vocational students' transition to working life is justified because it raises an important question about the changing labour market. In conditions of increasing precarity, does a successful transition to working life provide sufficient tools for maintaining an enduring sense of societal belonging? According to Wood (2017, 1186), labour market changes and the potential to attain adulthood via employment have noteworthy impacts on young people's experiences of belonging. Some scholars (e.g. Tolonen 2008; Maunu 2018; also, Nikunen and Korvajärvi 2020) have suggested that by choosing vocational education, young - predominantly working-class - people trust that they will obtain a profitable position in the labour market. Vocational education's social context may, furthermore, foster the political and ethical ideal of, for example, the worker-citizen, with expectations of achieving paid employment forming an important part of a young person's sense of belonging (Yuval-Davis 2006, 203, May 2011, 368; Isopahkala-Bouret et al. 2014, 101-102; Nylund et al. 2018 , 112). However, young people's hopes for a successful transition may prove unfounded, from the perspective of belonging, if their expectations of finding employment and a secure position in society are not met (May 2011, 370).

These critical considerations gain further credence through Nussbaum's (2011) capabilities approach (CA), which holds that every individual should be equally respected in society and society should guarantee them certain capabilities ${ }^{1}$ to support this ideal and the possibility of a decent life. Thus, CA provides a framework within which to debate both the politics and structures of belonging and the societal responsibilities of vocational education. In Nussbaum's $(2011,39)$ view, 'affiliation' (being a dignified part of the community) and 'practical reason' (being able to be true to one's self and direct one's life) are important because they connect to all other capabilities,

\footnotetext{
${ }^{1}$ Nussbaum (2011, 32-34) lists the central capabilities ensuring a decent life: (1) life, (2) bodily health, (3) bodily integrity, (4) senses, imagination and thought, (5) emotions, (6) practical reason, (7) affiliation, (8) other species, (9) play and (10) control over one's environment.
} 
such as bodily health, the emotions and control over one's environment. Also, CA facilitates an examination of the ideal of vocational education, whereby the successful transition to paid employment leads to graduates' societal participation as 'good (worker-)citizens' (Isopahkala-Bouret et al. 2014; Lappalainen et al. 2019). Such an ideal strengthens the social atmosphere in which, according to late modern theorists, vocational students may learn to think of their societal belonging as a personal responsibility and a personal success (Furlong and Cartmel 1997, 144; Beck and Beck-Gernsheim 2002, 24-25; Bauman 2005, 75-76). In this case, the structural frameworks and practices provided by society play an undetermined role in constructing the conditions of societal belonging. By considering the societal perspective and society's responsibilities, CA can enable a more accurate study of vocational students' visions of a decent post-transition life than previous approaches.

\section{Research Methods}

The data were collected within the context of the ALL-YOUTH research project. Six functional workshops were organised for vocational students from two Finnish education providers in autumn 2018 and spring 2019. The aim of the workshops was to explore students' expectations and concerns with regard to their transitions to working life.

The 58 students who participated in the workshops were from six vocational upper secondary programmes: Electrical Engineering and Automation Technology (two workshops); Social and Health Care; Business and Administration; Information and Communications Technology; Hotel, Restaurant and Catering Services; and Food Production. The method of empathy-based stories (MEBS) was applied in the beginning of the workshop. Using this method, the participants produced their own collective narratives in groups, imagining themselves in someone else's situation by making a collage from magazine clippings (Wallin et al. 2019, 525-526). The method was used as an orientation to the group interviews and to counter potential problems in the group interviews, such as reluctance among participants to express committed personal opinions in front of others, and to build a relaxed atmosphere for the discussions (Morgan 1997, 15-16; Wallin et al. 2019, 529-530). Because the participants had previously experienced working life mainly through work placements or traineeships, it was thought to be easier for them to approach the future working life from a third person's perspective by using MEBS.

The workshops proceeded as a two-phase process. In the first phase, the participants composed a visual output (a collage), in which they reflected on their expectations and concerns about their transition to working life from the perspective of either a successful or unsuccessful transition. They were given magazines, and the assigned task was to cut out pictures or words that they felt reflected either type of transition. In the second phase, the participants introduced their outputs to other students in the group interview sessions facilitated by the researchers. The interviews inquired into the participants' thoughts about their upcoming transition to working life and their future position in the labour market, as well as their understanding of a decent life.

The collected data (collages and recorded and transcribed group interviews) were analysed by focusing on the meanings the workshop participants attributed to their transition to working life. Thematic analysis (Braun and Clarke 2006) was used to 
allow the detailed categorisation of rich and varied data. The analysis was carried out in two steps. First, a data-driven, inductive approach was applied to the meanings given to successful or unsuccessful transitions (ibid., 83-84). The analysis began by mind mapping the themes found in the collages. The interview data were then processed, with a focus on the expectations and concerns the workshop participants associated with the transition to working life. In the second step, the analysis focused on the meanings the participants ascribed to social relationships and independence, social communities and societal expectations in their visions of a successful or unsuccessful transition to working life. This phase was more theory-driven because the thematisation was constructed around (1) the concept of belonging, i.e. the meanings the participants ascribed to post-graduation societal belonging, (2) Nussbaum's CA, with its definitions of affiliation and practical reason, i.e. how they explained their own and others' chances for meaningful social relationships and self-determination after the transition, and (3) 'the politics of belonging', i.e. what kinds of responsibilities they placed on themselves and others with regard to paid employment.

\section{Analysis: Working Life as a Guarantor of Societal Belonging}

This section describes how vocational students envision the elements of the 'decent life' promised to them upon their entry into working life. Based on the analysis, the workshop participants seemed to view a successful transition to working life as an essential prerequisite for societal belonging. Figure 1 presents the dimensions of their conception of belonging. In the following sections, the main findings of this paper and these dimensions of belonging will be presented and explained in greater detail.

\section{Self-acceptance-Achieving Independence and Being a Valued Worker}

According to the data, the workshop participants' visions of a successful transition can be divided into two categories along the dimension of self-

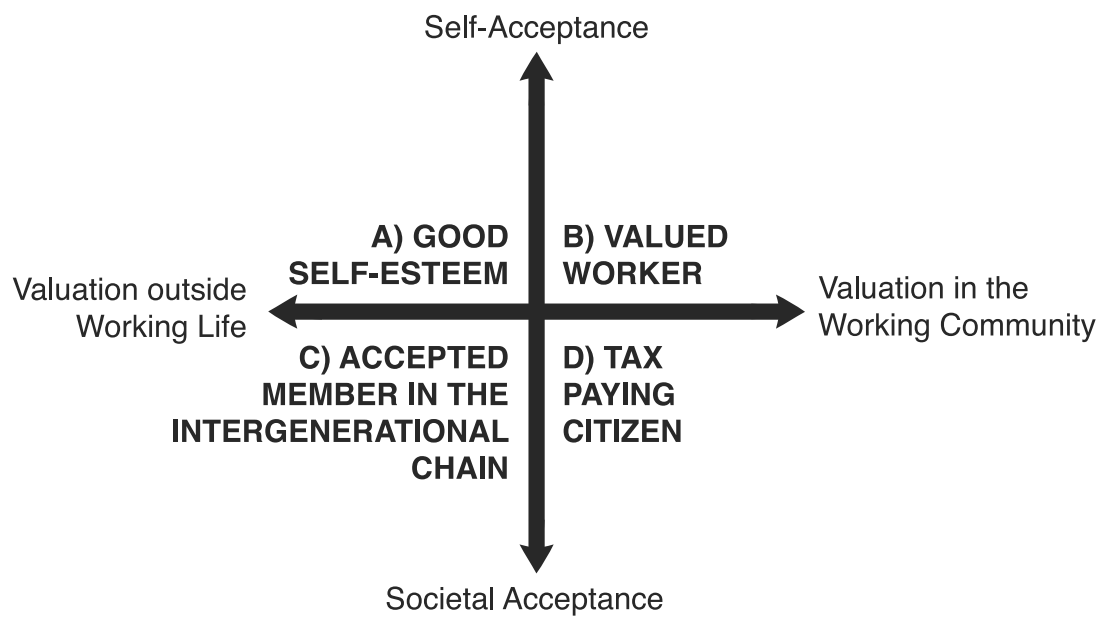

Fig. 1 Dimensions of belonging after the transition to working life 
acceptance (above the axis): being a valued worker and achieving independence and good self-esteem.

First, their visions highlight the meaning of belonging to a work community and their urge to be appreciated as skilled workers ( $\mathrm{B}-a$ valued worker). The chance to have a comfortable job where one feels valued and can utilise one's vocational competence was a central element of success in workshop participants' visions of a successful transition. The desire to feel appreciated within the work community relates to belonging as identification and emotional attachment (Yuval-Davis 2006, 202). The participants described the desire to be treated as professionals and gain responsibility, and some hoped that the work community would understand that they were new graduates. In either case, the feeling of being a welcomed and important part of the vocational community was central to their visions of a successful transition, as can be noted in the following quotes from various interviews:

$\mathrm{Y}^{2}$ : [The concern is that] the work community won't let you into the community and won't give good instructions for you but will, instead, assume that, now when you have graduated, you should know everything. And, furthermore, [they] won't advise or tell, for example, where one can find tools or what are the customs in the workplace.

Y2: [The hope regarding work] is to have a good work community and a good place to work so that you don't have to go to work every morning feeling annoyed. Instead, you are interested in what you are doing.

Second, the participating students' thoughts were connected to the ability to achieve a life of one's own (A - good self-esteem). In other words, finding a job where one feels a meaningful part of a work community and earning a salary were important signs of accomplishing independence after graduation. A successful transition meant the chance to determine one's life independently, regardless of anyone else's opinion or financial support (see also Chesters and Cuervo 2019, 235; Cuervo and Chesters 2019, 306307). In a similar fashion, previous studies have demonstrated that young people today place a high value on their autonomy - they yearn to determine for themselves what kind of life, adulthood and model of worker-citizenship they would like to embody (e.g. Mary 2012, 319-320; also Arnett 2004, 162). What is noteworthy is that, in the data, achieving independence was related to self-esteem, or, as one participant expressed:

Y3: Well, I wouldn't feel successful [in the transition] if I would have to live with KELA's [The Social Insurance Institution of Finland] money.

Furthermore, the workshop participants also attributed considerable value to social relationships outside working life, though they noted that maintaining

\footnotetext{
${ }^{2}$ The quotes are freely translated from Finnish. The code ' $\mathrm{Y}$ ' means a young person, and the numbering is used to distinguish the quotes from one another. Hence, the consecutive numbers do not indicate that the quotes are from the same interview. The quotes have been selected from various group interviews, and the representativeness of the workshops has been taken into account.
} 
meaningful social relations would be greatly hampered without income from paid employment to facilitate meaningful leisure time. To them, leisure time represents an important counterbalance to work because it allows one to recover and maintain social relationships. In addition, to many of the students, leisure time was more important than work. The ability to spend meaningful leisure time with friends was a significant personal goal in the participants' visions of a successful transition, which can be interpreted as a typical characteristic of today's consumer society (Bauman 2005, 38). Therefore, finding employment was a significant concern among the workshop participants. Without a paid job and an adequate salary, a person may become isolated from their social circles, and this may limit their opportunities to achieve independence. The next excerpts, taken from two different interviews in which participants are describing the importance of finding a job, provide good illustrations of this:

Y4: I think [the benefit of work] is the life itself. You won't get anything out of it if you're just at home eating and sleeping and watching TV. You must go out and be social with other people and explore the world, you know.

Y5: [Work is important], I suppose, so that you can become independent and are capable of taking care of your own affairs and also capable of buying the things that you need and living your life in general.

The findings above suggest that there is an association between students' understandings of a successful transition and Nussbaum's $(2011,34,39)$ practical reason-the freedom to plan one's own life - and that this association forms the basis of human dignity. They, moreover, connect with the capability of affiliation. Nussbaum (2011, 34) argues that, just as it is important to guarantee individuals' freedom to create and maintain social relationships, it is also important to ensure that one has a social basis for self-esteem and feels like a respected member of the community. With their visions of a successful transition, the participants placed a considerable value on employment for the sake of attaining desired independence and also an active social life. This value can be demonstrated with the following quote:

Y6: A person needs a job so that one can get money and have a chance to spend time with friends when one is free from work. If one, for example, plans to go for a longer vacation with friends or family, it usually requires a lot of money.

At the same time, the participants expressed that well-maintained social relationships, friends and family are the most crucial protection against social exclusion. Interestingly, they did not expect to become socially excluded themselves but relied on support from loved ones when needed, such as in the case of becoming unemployed. The importance of social relationships and what May $(2013,88)$ refers as 'alternative belonging' is evident in the following excerpt:

Y7: Whether you feel like you are part of the group depends quite a lot on the group that you are part of or, for example, on your group of friends. For instance, if a large number of people are unemployed, then one may not be so easily ashamed or anything like that, but if everyone else works, then maybe... 
Altogether, the findings demonstrate the participants' desire to feel accepted as part of their vocational community and social circles, which forms the foundation of one's experience of belonging (Anthias 2006, 21; May 2016, 759-760). These thoughts of the workshop participants seem to relate to self-acceptance, i.e. to the feeling that one has achieved one's own working life expectations and met the expectations of others. The following section explains how these findings depend on the value vocational students ascribe to social relationships and societal acceptance.

\section{Societal Acceptance-Realising the Expectations of Peers, Parents and Society}

Returning to Fig. 1, the dimension of societal acceptance (under the axis) can be divided into two complementary categories that demonstrate the meaning of belonging as follows: (C) members in the intergenerational chain and (D) tax paying citizens. These meanings were reflected in the views of the workshop participants, firstly, in how they felt it important to move forward in their life at the same pace with others in their social circles to receive appreciation from their peers, family and society. Second, the students viewed a paid job as a vital means of fulfilling their duties as taxpaying citizens (see also Ågren et al. 2020). Their viewpoints, in this regard, share similarities with the political and ethical value systems described by Yuval-Davis (2006, 203), which maintain possibilities for belonging (May 2016, 759). These value systems were reflected in the way the participants emphasised the importance of paid employment as the main means of belonging to society and, thus, reproduced the ideals of workercitizenship. This is interestingly evident in the following quote on basic income:

Y8: [Basic income] might make some people lazy and make them think that they don't have to do anything because they get the money anyway. Consequently, this laziness itself reduces human contacts and relationships with other people. This, on the other hand, worsens a person's mental state pretty badly. It might turn things even worse so that the person doesn't even want to do anything anymore.

Furthermore, despite the participants' sense that achieving independence is an important part of the transition to working life, it does not appear to be an entirely individualistic expectation. For example, in the next quote, a participant explains why they chose certain words for their collage on failed transitions:

Y9: ['Loneliness' and 'bullied' demonstrate a situation] where one's acquaintances, who are in working life, diminish or bully one for not getting ahead in one's life.

Rather, the longing for independence expresses an individual's need to be part of their peer group and advance in life at the same pace that they do (Nikunen and Korvajärvi $2020,12)$. It reflects the need, as well as the pressure, to take part in society in a wider sense, by fulfilling one's duties, achieving paid employment, and building one's life as a respectable taxpayer and consumer (Isopahkala-Bouret et al. 2014, 104-105). Furthermore, these visions demonstrate the need to realise the socially maintained conception of how the transition should progress and receive appreciation from the older 
generation (parents) and society at large. The next quote, in which one of the participants describes the value of work, is a vivid demonstration of this kind of thinking:

Y10: Probably, the most important thing is that you can take care of yourself so that others don't have to or that you don't have to live at others' mercy. And, moreover, that you are taking the responsibility for looking after yourself and do not assume that others will do it for you.

This finding illustrates that, for the participants, societal belonging is formed through other people's acceptance and the value system of worker-citizenship (May 2013, 83). It also indicates how the students aspire to negotiate their place in society by achieving paid employment (May 2011, 368-370). The need to belong to one's age group and become a full citizen is expressed in the desire for self-determination and self-realisation. The failure to realise this desire subsequently leads, according to the participants, to anxiety, shame, the loss of motivation and even giving up (May 2016, 759). The next quote summarises these views well:

Y11: [Getting fired] would crush one's self-esteem, and then, one might get depressed and no longer have the strength to apply for more jobs. After it, one would have nothing. One's whole world would break into pieces, for one has first studied for three years or more, and after finding a job, everything will nonetheless crush into pieces. Consequently, one would lose one's self-esteem and think that one has failed as a human being.

In young people's views, the dimensions of societal belonging are largely dependent on paid employment. However, as noted by the workshop participants, if one is supported by one's social circle, then a 'failed transition' may not be as detrimental as it otherwise would. The optimism of the students was also noteworthy because it manifested in their presumption that they will personally be able to obtain paid employment and, through it, a prestigious position in society. Such optimism has been noted also in some other studies (Mary 2012, 212-213; Franceschelli and Keating 2018; Nikunen and Korvajärvi 2020; also, Ågren et al. 2020). Although some participants acknowledged that anything could happen and that they might be temporarily unemployed at some point, most of them saw unemployment as a distant worry. Graduation also appeared to be a faraway event, even if they were already near graduation. However, according to previous research, these optimistic visions may become more realistic after entering an insecure working life (Mannerström et al. 2019, 1300).

\section{Discussion and Conclusion}

The findings of this study support the view that paid employment still provides an important foundation in vocational students' visions of societal belonging. Even though belonging is something that is constantly changing in a person's life (May 2013, 90), for the vocational students in this study, achieving paid employment offers an advantageous basis for societal belonging after graduation. What is interesting in the paper's 
analysis is that the impulse felt by the workshop participants to achieve independence and adulthood via paid employment stems from the aspiration for societal belonging.

The findings support May's $(2011,2013,2016)$ arguments about how gaining the acceptance of others plays an important role in building one's sense of belonging. In the views of the participants, the dimension of self-acceptance within societal belonging depends on how one succeeds in the transition in relation to one's peers or, as Nikunen and Korvajärvi $(2020,12)$ formulate it, competitors. Departing from the normative track or being forced outside of one's significant social groupings leads to a sense of not belonging after graduation. Furthermore, the data suggest that a person's selfacceptance is dependent on being accepted as a member in valued peer and social groups and in a work community. Therefore, the time spent with friends and family forms an important counterbalance to work and, further, enhances security and wellbeing within the precarious contemporary labour market. These observations are consistent with those of Furlong et al. (2011, 364), Cuervo and Wyn $(2014,902)$ and Batchelor et al. (2020, 105). To support vocational students' societal belonging, we may have to acknowledge the various meanings of one's social relationships - in terms of peer groups, leisure activities and work communities - as a pillar of one's selfacceptance within the worker-citizenship construct.

Accordingly, it is important to ask how the social structures and power relationships that reinforce the feeling of societal acceptance enhance young people's sense of societal belonging (Yuval-Davis 2006, 203). The findings demonstrate that workercitizenship plays the part of Yuval-Davis (2006) 'politics of belonging' within participants' visions of societal belonging. The participants have adopted the ideal of a responsible, taxpaying worker-citizen, as well as that of the consumer citizen (Bauman 2005, 38; Isopahkala-Bouret et al. 2014, 104-105). As noted, most also tended to believe in their personal chances of achieving the ideal. Following the interpretations of Nikunen and Korvajärvi $(2020,13)$ and Pyörï̈ et al. (2017, 9-11), this optimism is an attempt to negotiate the demands of worker-citizenship and, thus, also a defence mechanism because they count so much on their employment with regard to their post-graduation belonging. It may also reflect the trust they place either on their friends and family or on their education with regard to their future coping. It can be argued that the emphasis on a 'good worker-citizen' in vocational education gives the participants 'a false promise' regarding their position within a labour market facing insecurities and, thus, places a great deal of pressure on them in terms of employment (Furlong and Cartmel 1997, 144; Wyn and Dwyer 1999, 14).

The workshop participants desire acceptance in a work community that values and supports them and want to receive recognition for their vocational competence and as good workers. Hence, 'professionalism' appears to constitute the source of vocational students' sense of both societal and self-acceptance. For the students, finding a job in one's own field and being recognised as a qualified worker connote success as a worker-citizen, providing the means with which to live a decent life (Tolonen 2008; Maunu 2018; Nikunen and Korvajärvi 2020, 8-9). These observations resonate with Nussbaum's $(2011,39)$ theory, according to which the opportunity to develop the capabilities of affiliation and practical reason - that is, to feel like a dignified member of the community and plan one's own life - are the basis for human dignity. They, moreover, suggest that succeeding as a worker-citizen forms a crucial part of the studied students' visions of societal belonging. 
It can consequently be asked whether vocational education aims to guarantee students' sense of societal belonging by helping them attain the ideal of the workercitizen, and if this is so, how does that affect the experience of acceptance among those who cannot or refuse to fulfil this ideal. Following Nussbaum's $(2011,40)$ interpretation of CA, vocational education's responsibility to vocational students goes beyond the objective of paid employment, also touching on their sense of belonging and social participation. Therefore, vocational education institutions must work to guarantee at least the threshold level of social equality among students regardless of whether their transition to work succeeds or not (Edgell and Graham 2017, 1205).

In the same vein as Wood $(2017,1186)$, this paper argues that Finnish vocational education's narrow way of understanding societal participation via worker-citizenship impacts students' visions of how they can belong to society. Worker-citizenship is not completely a negative construct, because, for many vocational students, it can be an important resource of belonging. However, it is a resource only if young people are able to and want to meet its standards. As May $(2011,374 ; 2013,150)$ has argued, because the concept of belonging is sensitive to change, using it allows us to ask how and to whom we can ensure belonging, especially when society is changing. The findings of this paper contribute to discussing how vocational education can support students' actual potential to find paid employment as expected and desired (whether full-time, part-time or entrepreneurship).

When interpreting the results, it is important to remember that young people enter vocational education from diverse backgrounds and that employment prospects vary considerably by degree field. It is also noteworthy that the assignment in the workshops was oriented around the transition to working life and may have strengthened the role of paid employment in the analysis. It may be that the research situation or methods led some of the participants to overemphasise paid employment. For instance, it seemed as if the students were attempting to convince the interviewer of their decency as 'workercitizens' (see Ågren et al. 2020). These are interesting points, nevertheless, in the light of the research questions. The themed interview questions helped the interviewers broaden the topics discussed beyond paid employment.

In conclusion, this paper poses an important and timely question for future research. How can vocational education and society in general support vocational education graduates, particularly their sense of societal belonging, prior to their uncertain transition to working life? This is a particularly relevant question considering the negative effects of the insecure labour market on young people's well-being and opportunities to plan for their future (Vancea and Utzet 2018; Cuervo and Chesters 2019).

Code Availability Not applicable.

Author Contribution Not applicable.

Funding The study is supported by ALL-YOUTH - All Youth Want to Rule Their World Research Project 2018-2023. The project is funded by the Strategic Research Council (SRC)/the Academy of Finland (grant numbers 312689 and 312692).

Data availability The data are available for the ALL-YOUTH research project. Not all participants gave permission for the open distribution of data. 


\section{Declarations}

Ethical Approval All procedures performed in the study followed the ethical guidelines of the Finnish National Board on Research Integrity (TENK). Ethical review was not needed as the study did not collect sensitive and identifiable data.

Informed Consent All participants were clearly informed about their rights in data collection at the beginning of the workshops. Participation was voluntary, and the participants signed a consent form. The forms are stored in accordance with GDPR guidelines.

Conflict of Interest The author declares no competing interests.

Open Access This article is licensed under a Creative Commons Attribution 4.0 International License, which permits use, sharing, adaptation, distribution and reproduction in any medium or format, as long as you give appropriate credit to the original author(s) and the source, provide a link to the Creative Commons licence, and indicate if changes were made. The images or other third party material in this article are included in the article's Creative Commons licence, unless indicated otherwise in a credit line to the material. If material is not included in the article's Creative Commons licence and your intended use is not permitted by statutory regulation or exceeds the permitted use, you will need to obtain permission directly from the copyright holder. To view a copy of this licence, visit http://creativecommons.org/licenses/by/4.0/.

\section{References}

Anthias F (2006) Belongings in a globalising and unequal world: rethinking translocations. In: Yuval-Davis N, Kannabirān K, Vieten U (eds) The situated politics of belonging. SAGE Publications, London, pp 17-31

Antonsich M (2010) Searching for belonging - an analytical framework. Geogr Compass 4(6):644-659. https://doi.org/10.1111/j.1749-8198.2009.00317.x

Arnett JJ (2004) Emerging adulthood: the winding road from the late teens through the twenties. Oxford University Press, New York

Aronson P (2008) The markers and meanings of growing up: contemporary young women's transition from adolescence to adulthood. Gend Soc 22(1):56-82. https://doi.org/10.1177/0891243207311420

Ågren S, Pietilä I, Rättilä T (2020) Palkkatyökeskeisen ajattelun esiintyminen ammattiin opiskelevien työelämäasenteissa [Paid-employment-centred thinking in the working life attitudes of vocational education students]. In: Haikkola L, Myllyniemi S (eds) Hyvää työtä! Nuorisobarometri 2019. [Good work! Youth Barometer 2019]. Valtion nuorisoneuvosto, Nuorisotutkimusseura, Nuorisotutkimusverkosto, Opetus- ja kulttuuriministeriö, Helsinki, pp 157-178

Batchelor S, Fraser A, Whittaker L, Li L (2020) Precarious leisure: (re)imagining youth, transitions and temporality. J Youth Stud 23(1):93-108. https://doi.org/10.1080/13676261.2019.1710483

Bauman Z (2005) Work, consumerism and the new poor, 2nd edn. Open University Press, Maidenhead

Beck U, Beck-Gernsheim E (2002) Individualization: institutionalized individualism and its social and political consequences. SAGE, London and Thousand Oaks, California

Braun V, Clarke V (2006) Using thematic analysis in psychology. Qual Res Psychol 3(2):77-101

Chesters J, Cuervo H (2019) Adjusting to new employment landscapes: consequences of precarious employment for young Australians. Econ Labour Relat Rev 30(2):222-240. https://doi.org/10.1177/ 1035304619832740

Cuervo H, Chesters J (2019) The [im]possibility of planning a future: how prolonged precarious employment during transitions affects the lives of young Australians. Lab Ind: J Soc Econ Relat Work 29(4):295-312. https://doi.org/10.1080/10301763.2019.1696654

Cuervo H, Wyn J (2014) Reflections on the use of spatial and relational metaphors in youth studies. J Youth Stud 17(7):901-915. https://doi.org/10.1080/13676261.2013.878796

Cuervo H, Wyn J (2016) An unspoken crisis: the 'scarring effects' of the complex nexus between education and work on two generations of young Australians. Int J Lifelong Educ 35(2):122-135. https://doi.org/10. $1080 / 02601370.2016 .1164467$ 
Edgell V, Graham H (2017) A capability approach to unemployed young people's voice and agency in the development and implementation of employment activation policies. Soc Pol Admin 51(7):1191-1209. https://doi.org/10.1111/spol.12262

Franceschelli M, Keating A (2018) Imagining the future in the neoliberal era: young people's optimism and their faith in hard work. Young 26(4):1-17. https://doi.org/10.1177/1103308817742287

Furlong A, Cartmel F (1997) Young people and social change. Individualization and risk in late modernity. Open University Press, Buckingham

Furlong A, Cartmel F (2007) Young people and social change: new perspectives. Open University Press, Maidenhead

Furlong A, Woodman D, Wyn J (2011) Changing times, changing perspectives: reconciling 'transition' and 'cultural' perspectives on youth and young adulthood. J Sociol 47(4):355-370. https://doi.org/10.1177/ 1440783311420787

Isopahkala-Bouret U, Lappalainen S, Lahelma E (2014) Educating worker-citizens: visions and divisions in curriculum texts. J Educ Work 27(1):92-109. https://doi.org/10.1080/13639080.2012.718745

Kerr S, Maczulskij T, Maliranta M (2020) Within and between firm trends in job polarization: the roles of globalization and technology. J Econ Geogr 20(4):1003-1039. https://doi.org/10.1093/jeg/lbz028

Lähdesmäki T, Saresma T, Hiltunen K et al (2016) Fluidity and flexibility of "belonging": Uses of the concept in contemporary research. Acta Sociol 59(3):233-247. https://doi.org/10.1177/0001699316633099

Lappalainen S, Nylund M, Rosvall PÅ (2019) Imagining societies through discourses on educational equality: a cross-cultural analysis of Finnish and Swedish upper secondary curricula from 1970 to the 2010s. Eur Educ Res J 18(3):335-354. https://doi.org/10.1177/1474904118814140

Mannerström R, Muotka J, Salmela-Aro K (2019) Associations between identity processes and success in developmental tasks during the transition from emerging to young adulthood. J Youth Stud 22(9):12891307. https://doi.org/10.1080/13676261.2019.1571179

Mary A (2012) The illusion of the prolongation of youth. Dissertation, University of Tampere

Maunu A (2018) Arjen rytmit ja yhteisöt - ammattiin opiskelevien hyvä elämä ja haalistuva individualismi [Routines, social groups and everyday life. Vocational students' conceptions of a good life and fading individualism]. Nuorisotutkimus 36(1):3-21

Maury O (2020) Between a promise and a salary: student-migrant-workers' experiences of precarious labour markets. Work Employ Soc 34(5):809-825. https://doi.org/10.1177/0950017019887097

May V (2011) Self, belonging and social change. Sociology 45(3):363-378. https://doi.org/10.1177/ 0038038511399624

May V (2013) Connecting self to society: belonging in a changing world. Palgrave Macmillan, Basingstoke

May V (2016) When recognition fails: mass observation project accounts of not belonging. Sociology 50(4): 748-763. https://doi.org/10.1177/0038038515578991

Morgan DL (1997) Focus groups as qualitative research. SAGE Publications, Thousand Oaks

Myllyniemi S, Haikkola L (2020) Tilasto-osio [Statistics].In: Haikkola L, Myllyniemi S (eds) Hyvää työtä! Nuorisobarometri 2019. [Good work! Youth Barometer 2019]. Valtion nuorisoneuvosto, Nuorisotutkimusseura, Nuorisotutkimusverkosto, Opetus- ja kulttuuriministeriö, Helsinki, pp 9-108

Nikunen M, Korvajärvi P (2020) Being positive, being hopeful, being happy: young adults reflecting on their future in times of austerity. Eur J Cult Stud. https://doi.org/10.1177/1367549420935901

Nussbaum M (2011) Creating capabilities: the human development approach. Belknap Press of Harvard University Press, Cambridge, MA and London

Nylund M, Rosvall PÅ, Eiríksdóttir E et al (2018) The academic-vocational divide in three Nordic countries: implications for social class and gender. Educ Inq 9(1):97-121. https://doi.org/10.1080/20004508.2018. 1424490

Ojala S, Nätti J, Lipiäinen L (2018) Types of temporary employment: an 8-year follow-up of labour market attachment. Soc Indic Res 138(1):141-163. https://doi.org/10.1007/s11205-017-1648-7

Pajarinen M, Rouvinen P, Ekeland A (2015) Computerization threatens one-third of Finnish and Norwegian employment. ETLA [The Research Institute of the Finnish Economy] Brief. https://www.etla.fi/wpcontent/uploads/ETLA-Muistio-Brief-34.pdf. Accessed 11 November 2020

Pyöriä P, Ojala S (2016) Precarious work and intrinsic job quality: evidence from Finland, 1984-2013. Econ Labour Relat Rev 27(3):349-367. https://doi.org/10.1177/1035304616659190

Pyöriä P, Ojala S, Saari T, Järvinen KM (2017) The millennial generation: a new breed of labour? SAGE Open 7(1):1-14. https://doi.org/10.1177/2158244017697158

Rasmussen S, Nätti J, Larsen TP, Ilsøe A, Garde AH (2019) Nonstandard employment in the Nordics - toward precarious work? Nord J Work Life Stud 9(6):7-32. https://doi.org/10.18291/njwls.v9iS6.114689

Rintala H, Nokelainen P (2018) Työn murros haastaa ammatillisen koulutuksen. Talous \& Yhteiskunta 46(2): 56-60 
Tolonen T (2008) Menestys, pärjääminen ja syrjäytyminen. Nuorten elämäntyylit ja luokkaerot. [Success, coping and social exclusion. Youth lifestyles and class differences.]. In: Tolonen $\mathrm{T}$ (ed) Yhteiskuntaluokka ja sukupuoli [Social Class and Gender]. Vastapaino, Tampere, pp 226-254

Vancea M, Utzet M (2018) School-to-work transition: the case of Spanish NEETs. J Youth Stud 21(7):869887. https://doi.org/10.1080/13676261.2017.1421313

Wallin A, Koro-Ljungberg M, Eskola J (2019) The method of empathy-based stories. Int J Res Method Educ 42(5):525-535. https://doi.org/10.1080/1743727X.2018.1533937

Wood BE (2017) Youth studies, citizenship and transitions: towards a new research agenda. J Youth Stud 20(9):1176-1190. https://doi.org/10.1080/13676261.2017.1316363

Wyn J, Dwyer P (1999) New direction in research on youth in transition. J Youth Stud 2(1):5-21. https://doi. org/10.1080/13676261.1999.10593021

Wyn J, White R (1997) Rethinking youth. SAGE Publications, London

Yuval-Davis N (2006) Belonging and the politics of belonging. Patterns Prejudice 40(3):197-214. https://doi. org/10.1080/00313220600769331 